Note

\section{High Cell Density Culture of a Hybridoma Using Perfluorocarbon to Supply Oxygen}

\author{
Kimihiko Намамото, ${ }^{*}$ \\ Michiyuki TOKASHIKI, ${ }^{*}$ Yataro ICHIKAWA* \\ and Hiroki MuraKamI** \\ *Biotechnology Research Laboratory, \\ Teijin Limited, Hino, \\ Tokyo 191, Japan \\ **Department of Food Science and Technology, \\ Faculty of Agriculture, Kyushu University, \\ Fukuoka 812, Japan
}

Received June 30, 1987

In order to culture animal cells in suspension at high density, the supply of an ample amount of oxygen is an important requisite. An insufficient oxygen supply to a culture results in poor growth of the cells or a poor yield of the products. Aeration with gaseous oxygen is the most widely used method for supplying oxygen to a suspension cell culture system, but cells suffer some damage due to the aeration, especially in a high cell density culture. Although for bacterial fermentations various methods have been reported, ${ }^{1 \sim 4)}$ little work has been done to develop new methods for supplying oxygen to a high cell density culture system.

The purpose of this investigation was to develop a novel oxygen supply system. In the system developed, oxygenized liquid perfluorocarbon is fed into the culture vessel as an oxygen carrier, oxygen being supplied to the cells by means of cell-liquid contact. After the release of oxygen, the liquid perfluorocarbon sediments to the cone-shaped bottom of the vessel, because of its high specific gravity and insolubility in the medium. The perfluorocarbon is then conducted to an separate vessel to be oxygenized again with gaseous oxygen. Cells are supplied with oxygen through the oxygenation-deoxygenation cycle of perfluorocarbon. Gaseous oxygen is highly soluble in perfluorocarbon, the solubility being about ten times that in water, and perfluorocarbon has actually been studied as artificial blood, both in animals and humans. The specific gravity of the liquid ranges from 1.6 to 1.9 , which makes it easy for the liquid to be separated from the culture medium.

The perfluorocarbon employed in the present study was Fluorinert FC-40 (3-M, St. Paul, MN, U.S.A.). Some properties of $\mathrm{FC}-40$ are as follows: boiling point, $155^{\circ} \mathrm{C}$; specific gravity, 1.85 ; solubility of gaseous oxygen (1atm, $\left.25^{\circ} \mathrm{C}\right), 37 \mathrm{ml} / 100 \mathrm{ml} \mathrm{FC}-40$.
Figure 1 shows a scheme of the system used. This system comprised a culture vessel, a new medium flask, apparatus for solubilizing oxygen in the perfluorocarbon and three peristaltic pumps.

The culture vessel $(165 \mathrm{~mm} \times 80 \mathrm{~mm})$ and aerator $(500 \mathrm{~mm} \times 50 \mathrm{~mm})$ were made of glass and all the tubing was composed of silicone. The culture vessel was equipped with a dissolved oxygen (DO) sensor (Oriental Yeast Co., Ltd.) and a spinner filter made of sintered stainless steel (pore size, 10 microns; area, $95 \mathrm{~cm}^{2}$ ). $225 \mathrm{ml}$ of RPMI 1640 medium containing $10 \%$ fetal calf serum (FCS) was charged into the culture vessel and then mouse-mouse hybridoma 4C10B6 (parent: $\mathrm{P} 3 / \mathrm{x} 63-\mathrm{Ag} \cdot \mathrm{U} 1$ ) cells that secreted $\mathrm{IgG}_{2 \mathrm{~b}}$ were inoculated at density of $1.5 \times 10^{5}$ cells $/ \mathrm{ml}$. Air containing $5 \% \mathrm{CO}_{2}$ was passed over the surface of the culture medium. The cells were cultured at $37^{\circ} \mathrm{C}$. The filter was rotated by a motor on the top of the culture vessel and the medium was stirred at $150 \mathrm{rpm}$. Living cell numbers were determined with a hemacytometer after trypan blue staining, and the concentration of IgG in the medium was determined by an enzymelinked immunosorbent assay (ELISA).

The growth of hybridoma 4C10B6 cells, and the concentration and productivity of IgG are collectively shown in Fig. 2. On the 4 th day the concentration of living cells was found to be $9.2 \times 10^{5}$ cells $/ \mathrm{ml}$ and fresh medium was continuously fed at a rate of $225 \mathrm{ml} /$ day from line 1 in Fig. 1. Simultaneously, spent medium was continuously separated from cells by the rotating filter and conducted out of the system through line 2 by a peristaltic pump so that the volume of culture liquid in the vessel remained constant at $225 \mathrm{ml}$. The amount of the medium fed into the culture vessel was increased to $700 \mathrm{ml} /$ day as the cell density increased. On the 7th day, the supply of air containing $5 \%$ $\mathrm{CO}_{2}$ was stopped and the oxygen supply using perfluorocarbon was started. The oxygenized perfluorocarbon was added to the aqueous medium dropwise from the top of the culture vessel. The perfluorocarbon coalesed in the FC-40 phase (maintained at about $3 \mathrm{~cm}$ height) was

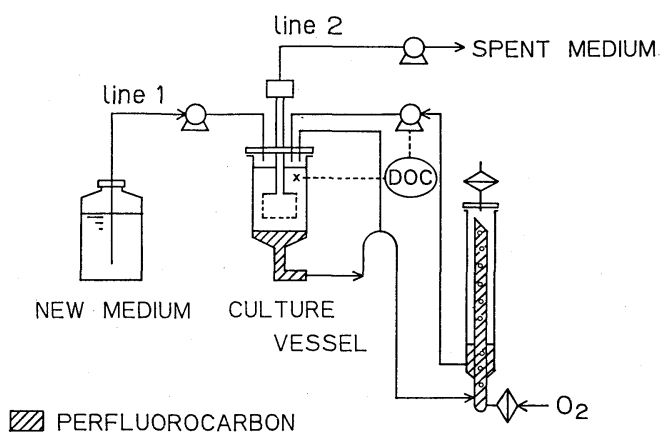

Fig. 1. Scheme of the Culture System for High Density Culture of 4C10B6 Mouse-Mouse Hybridoma Cells.

New medium was fed into the culture vessel via line 1 and spent medium was removed via line 2 . 


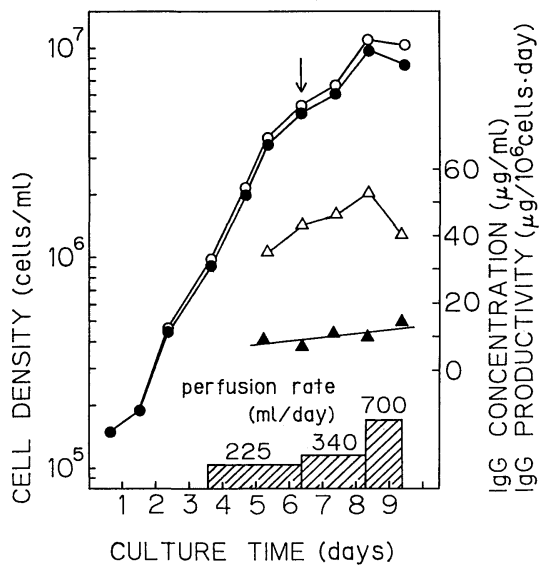

FIG. 2. Growth and IgG Production in a High Density Culture of Hybridoma 4C10B6 Cells.

Cells were cultured in 10\% FCS-RPMI 1640 medium in the system shown in Fig. 1. The numbers of total $(O)$ and viable (O) cells were determined with a hematocytometer. The concentration of $\operatorname{IgG}(\triangle)$ was determined by ELISA and the IgG productivity $(\boldsymbol{\Delta})$ of the hydridoma cells was calculated from the total cell number and the concentration of IgG. After 7-day culture, oxygen was supplied to the system using perfluorocarbon as an oxygen carrier (indicated by an arrow).

continuously removed from the culture vessel, reaerated with oxygen gas and repeatedly used. The culture vessel contained $100 \mathrm{ml}$ of FC-40, and the total volume of the perfluorocarbon in the system was $300 \mathrm{ml}$. The concentration of dissolved oxygen was monitored with DO sensor and maintained at $3 \mathrm{ppm}$ by controlling the flow of perfluorocarbon with a peristaltic pump. Sufficient oxygen was supplied using perfluorocarbon as an oxygen carrier for the hybridoma cells to grow, because the hybridoma cells had proliferated up to the maximum cell density of $9.8 \times 10^{6}$ cells $/ \mathrm{ml}$ on the 9 th day. The viability of the hybridoma cells did not change $(>95 \%$ ), and the concentration and productivity of IgG remained almost constant throughout the culture.

In this experiment it was demonstrated that perfluorocarbon was capable of supplying so much oxygen that cells could attain to such a high density as $9.8 \times 10^{6}$ cells $/ \mathrm{ml}$. Mouse-mouse hybridoma $4 \mathrm{C} 10 \mathrm{~B} 6$ cells are rather strong as to aeration, so the results above did not show that the use of perfluorocarbon as an oxygen carrier was decidedly superior to aeration. But this method will make it possible to culture feeble cells that suffer serious damage due to aeration.

\section{REFERENCES}

1) O. Holst, S. O. Enfors and B. Mattiasson, Eur. J. Appl. Microbiol. Biotechnol., 14, 64 (1982).

2) P. Adlercreutz and B. Mattiasson, Enzyme Microbiol. Technol., B 36, 651 (1982).

3) M. Ibrahim and H. G. Schlegel, Biotechnol. Bioeng., 22, 1877 (1980).

4) D. Damiano and S. S. Wang, Biotechnol. Lett., 7, 81 (1985). 